\title{
ESTUDO DA ETNOBIOLOGIA E INTERVENÇÕES DA POPULAÇÃO RIBEIRINHA NA BARRAGEM CACHOEIRA, MUNICÍPIO DE AURORA-CE, COMO FORMA DE PROTEÇÃO DO BIOMA LOCAL
}

\author{
SAYRO RHUAN SANTOS LUNA | IFPB \\ DARIO OLIVEIRA NETO | IFPB \\ GASTÃO COELHO FILHO AQUINO, M. SC.| IFPB
}

\section{INTRODUÇÃO}

"A necessidade de utilizar água com sabedoria é evidente, uma vez que, esta é um recurso limitado" (PESSOA et al., 2015), embora possamos constatar o absurdo que ainda hoje se observa no desperdício indiscriminado de água. No sítio Biologo (s.d.): "Etnobiologia é o ramo da Biologia que trata da relação entre sociedades humanas, [...] e as plantas e animais do seu ambiente".

A Barragem Cachoeira localizada na Cidade de Aurora-Ceará, abastece a população rural e urbana do município, incluindo duas comunidades situadas às suas margens: os Sítios Cachoeira Caiçara.

Este trabalho visou investigar as relações culturais e socioambientais da população ribeirinha, através de contatos com as relações do Bioma Caatinga, estabelecendo as classificações biológicas com as percepções e conceitos estabelecidos pela comunidade, analisando as suas intervenções e propondo medidas educativas que possam se transformar em ações concretas de proteção da fauna e da flora, protegendo as margens e matas ciliares e construindo uma estreita relação entre valores sociais da comunidade e o Instituto Federal da Paraíba, enquanto agente transformador, na expectativa de mudança de consciência em busca de uma comunidade próspera e protetora do ambiente.

\section{METODOLOGIA}

Utilizando os conhecimentos etnobiológicos e culturais, envolvendo as comunidades, foram feitas visitas à população coletando dados referentes a percepção da fauna e da flora do local, meios de utilização e beneficiamento da água do açude. O órgão gerenciador do açude Cachoeira, a COGERH (Companhia de Gestão de Recursos Hídricos) disponibilizou dados do volume de água do açude e da vazão liberada desde o ano de 2005 até 2019 , sendo esses dados utilizados para produzir um mapa no programa QGis, com intuito de melhor referenciar o local, evidenciando as áreas com maior desenvolvimento biológico entre os períodos de seca e cheia. Foi utilizada a Equação de Blaney-Criddle (TOMAZ, 2008) como referência no cálculo da evapotranspiração, para comprovar que, com o aumento da mata ciliar tem-se um menor índice de evaporação das águas da barragem cachoeira.

\section{RESULTADOS}

A pesquisa possibilitou o conhecimento das comunidades do município no entorno do açude. Foi possível identificar e incentivar o plantio de plantas nativas como catingueira (Caesalpinia pyramidalis), mulungu (Erythrina mulungu) e algodão do mato (Cochlospermum Insigne). Podemos entender que a construção do açude foi um alívio para a população, que não tinha a água de boa qualidade para atender às necessidades básicas, incentivando assim boas práticas de conservação.

No mapa mostrado na Figura 1, podemos observar o açude e as comunidades marginais ao açude.

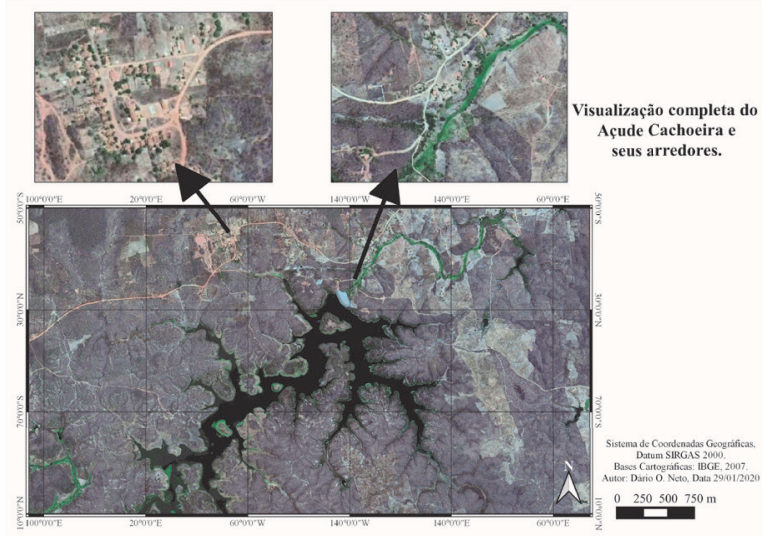

Figura 1 - Açude Cachoeira e as Comunidades. Fonte: 0 s autores (2020). 


\section{REFERÊNCIAS}

BIOLOGO, s.d. Disponível em https://biologo.com.br/ bio/etnobiologia/. Acesso em 16 abr. 2019.

COGERH. Avaliação mensal da situação dos açudes. Disponível em https://portal.cogerh.com.br/avaliacao-mensal-da-situacao-dos-acudes-2019/. Acesso em 16 abr. 2019.

PESSOA, J. J. da S. et al. Dispositivo prático e econômico de anti contaminação bacteriana e viral utilizado em torneiras. In: XV Semana de Economia da URCA: Escassez de Recursos Hídricos e Grandes Projetos Econômicos no Nordeste. [Anais]. V. 1, Crato-CE, 2015. Disponível em https://docplayer.com.br/89410405-Anais-issn.html. Acesso em 16 abr. 2019.

TOMAZ, Plínio. Método de blaney-criddle, 1975 para evapotranspiração de referência ETo. 2008. Disponível em http://www.pliniotomaz.com.br/downloads/livros/livro_evapotranspiracao/capitulo09.pdf. Acesso em 06 abr. 2019. 